\title{
Monetary and Social Rewards for Crowdsourcing
}

\author{
Francesco Cappa ${ }^{1, * \mathbb{C}}$, Federica Rosso ${ }^{2} \mathbb{D}$ and Darren Hayes ${ }^{3(\mathbb{D}}$ \\ 1 Department of Business and Management, LUISS Guido Carli University, Viale Pola 12, 00198 Rome, Italy \\ 2 Department of Civil, Construction and Environmental Engineering, Sapienza University of Rome, Via \\ Eudossiana 18, 00184 Rome, Italy; federica.rosso@uniroma1.it \\ 3 Seidenberg School of Computer Science \& Information Systems, Pace University, One Pace Plaza, New York, \\ NY 10038, USA; dhayes@pace.edu \\ * Correspondence: fcappa@luiss.it; Tel.: +39-06-85225457
}

Received: 1 May 2019; Accepted: 15 May 2019; Published: 17 May 2019

\begin{abstract}
Crowdsourcing of inventive activities is a particular form of crowdsourcing that helps firms to innovate by involving dispersed individuals to exploit "crowd wisdom". In this context, the greater the number of contributions, the greater the possibility to gather extremely valuable ideas to produce innovative products and services. While monetary and social rewards can be an effective means to boost contributors' extrinsic and intrinsic motivations to contribute, a theoretical understanding and empirical evidence of their effects are lacking. This paper focused on the crowdsourcing of inventive activities, initiated by listed companies worldwide, from 2007 to 2014 . Our findings shed light on the influence of monetary and social rewards on the number of ideas collected. In particular, we analyzed the impact on the number of contributions brought about by monetary rewards and noted a positive influence related to its presence and also a negative effect related to the amount of the compensation. Moreover, we have demonstrated how the presence of a social cause is beneficial to the number of contributions. Consequently, we contribute to a scholarly understanding of the crowdsourcing phenomenon and we have provided guidance to managers seeking to initiate crowdsourcing campaigns.
\end{abstract}

Keywords: crowdsourcing; rewards; monetary reward; social benefit; Open Innovation; Open Sustainable Innovation

\section{Introduction}

Over the past few decades, the innovation model for companies has gradually shifted towards the adoption of Open Innovation (OI) practices, where organizations involve external partners, such as other companies, universities, and suppliers [1-5]. In bygone years, the innovative process took place inside the firms' boundaries, while the aim of OI has traditionally been to open the innovation box, thereby creating a network of entities that can benefit from diverse contributions that can deliver innovative products and services [6-8]. Different "directions" of OI can be exploited by organizations: (i) Inbound, where contributions come from beyond the companies' boundaries, (ii) outbound, where the companies themselves contribute to innovation processes, and finally (iii) coupled, where the internal and external flows are combined [6,9].

Thanks to recent advancements in information technologies, amongst the potential partners involved in OI practices, the involvement of individuals from outside organizational boundaries, connecting through the Internet, is increasing [10-12]. This growing inbound OI phenomenon was coined "crowdsourcing" by Jeff Howe [13] a decade ago and refers to outsourcing the firm's innovation effort to the crowd. Brabham [14] appropriately defined crowdsourcing as an "online, distributed problem solving and production model whereby an organization leverages the collective intelligence of an online community for a specific purpose". In fact, accessing the crowd, i.e., a significant number 
of dispersed individuals, from which to gather diverse and stimulating ideas, has been shown to benefit a firm's innovation process $[15,16]$. Indeed, through crowdsourcing, it is possible to exploit a diverse knowledge base from disparate individuals, to tap into the so-called "crowd wisdom" [17,18]. Consequently, it is possible to leverage the skills and talents of individuals from outside firm boundaries, which are different from existing ones within the organization [15,19-21]. By so doing, companies may link disconnected external sources of knowledge with their internal resources in order to foster innovations [17,22]. Based on the aforementioned reasons, crowdsourcing is increasingly being used worldwide, and the number of contributors has almost doubled every year since the term was first coined by Jeff Howe. That number reached seven million in 2012 [23]. Moreover, crowdsourcing has attracted great attention from academics and has resulted in almost 1000 publications being added to the Scopus database between 2006 and 2015 [24]. While crowdsourcing is a recent phenomenon, according to Afuha and Tucci [25] there is plenty of room to add value to this very relevant subject.

There are different typologies of crowdsourcing, e.g., devoted to performing routine activities or creating marketing campaigns, and in this study, we focused on the "crowdsourcing of inventive activities", i.e., the typology dedicated to helping companies to develop innovative products and services. In this context, a crucial aspect of effective crowdsourcing is the collection of valuable ideas from the crowd. The value of the contributions gathered by companies, to deliver innovative products and services, depends upon the number of contributors that join a crowdsourcing campaign [26,27]. There is a direct link between the number of contributions and the overall quality of the contributions collected [28,29]. Indeed, the broader the set of available ideas, the more a firm will be able to innovate $[26,27,30,31]$. Therefore, finding ways to increase the number of contributions in "crowdsourcing of inventive activities" represents an important research problem for both academics and firms alike. In this study, we focused on the impact brought about by different kind of rewards in motivating individuals to participate with the goal of increasing the number of contributions and consequently improve the quality of the outcomes. Crowdsourcing participants, as in other crowd-based projects, are motivated in two different ways: Leveraging extrinsic and intrinsic motivations [32-34]. The former category is related to individuals contributing with the expectation of some kind of return $[14,35]$, while the latter is connected to self-determination based on a social cause without any immediate benefit for the contributors [32,36,37]. Therefore, individuals participate because they wish to be rewarded monetarily, or because they enjoy sharing their ideas to achieve a goal that will benefit society, or for both of the aforementioned reasons. Thus, the motivation to participate can be positively affected by rewards that leverage extrinsic and intrinsic motivations [29,38]. Consequently, in this study, we sought to test and quantify the effects brought about by two different types of rewards. In particular, we addressed the following research question: Do monetary and social rewards increase the number of contributions in crowdsourcing?

While previous research investigated the impact of rewards to encourage participation in open source communities or citizen science initiatives [39-42], the goal of this study was to analyze the impact of different types of rewards, i.e., based on money and social cause, on the number of contributions in "crowdsourcing of inventive activities" campaigns. In addition, we provide a theoretical grounding for the effects brought about by increasing extrinsic and intrinsic motivations through rewards in crowdsourcing, based on fairness expectation and self-determination theories [32,36,37,43-47]. Moreover, in this study, we analyzed the effect of each type of reward when both kinds of rewards are present. Furthermore, while previous studies have focused on crowdsourcing campaigns conducted in a single country or through a single integrator web-based platform [48,49], this study included calls for ideas initiated by listed companies worldwide and managed through their own website, thereby increasing the generalizability and relevance of the results. Therefore, gathering evidence on the influence of monetary and social rewards can create a better understanding of the crowdsourcing phenomenon and can provide managers with clearer guidance on how to increase the number of crowdsourcing contributions. This will, in turn, benefit the quality of the innovative outcomes. 
The paper is organized as follows: Section 2 provides the background and the theory underlying the formulation of the three hypotheses proposed. Section 3 describes the employed method of data analysis, with the identification of independent and dependent variables and an explanation of the regression analysis conducted. In Section 4 we detail the results of our study. In Section 5 we discuss the implications of our results and limitations of the study, while Section 6 provides concluding remarks on the research.

\section{Background and Hypotheses}

Crowdsourcing is an increasingly adopted OI practice and has attracted growing academic interest over the past few years [24,31,50-54]. Thanks to advancements in information technology, it has become easier for companies to reach dispersed individuals and leverage crowd wisdom [10,55-59]. Indeed, online participation facilitates collaboration with individuals [60-62], by overcoming participants' physical, social, cultural and geographical barriers [38,62,63]. From the inclusion of lead users, i.e., interacting with a few selected customers, the emphasis for companies is to reach out to numerous volunteer participants [64-68]. Depending on the specific goals that an organization aims to achieve, by leveraging crowdsourcing, we can distinguish between "crowdsourcing of inventive activities", "crowdsourcing of routine activities" and "crowdsourcing of content" [69]. The "Crowdsourcing of routine activities" is related to externalizing repetitive activities to the crowd, without any prerequisite knowledge requirements and heterogeneity among individuals. "Crowdsourcing of content" leverages dispersed individuals to collect large amounts of data, again without any prerequisite knowledge requirement for the crowd, while in this case, the heterogeneity of individuals is relevant to collecting useful data. Finally, "crowdsourcing of inventive activities" leverages the heterogeneity of the crowd to provide solutions to complex problems that the firm cannot solve based solely on its own internal resources. Instead of involving individuals in the co-creation of a new product or service, i.e., collaborating throughout the new product development process $[70,71]$, the focus is on leveraging an undefined crowd for collecting innovative ideas. This last form of crowdsourcing, also referred to simply crowdsourcing in the rest of the paper for the sake of brevity, is one that is more oriented towards innovation and represents the focus of our research.

Organizing a call for ideas is quite demanding for companies in terms of administering an online campaign and evaluating the submitted proposals [15,72-74], while the goal is to maximize the benefits of a campaign by collecting extremely valuable ideas, which can be profitably implemented for commercial usage [28]. To this aim, the greater the number of contributions, the more that companies can improve their innovation efforts since more ideas can lead to more innovative products and services [28]. Thus, motivating people to participate in a crowdsourcing call is critical for a successful crowdsourcing campaign. However, previous literature focused primarily on crowdsourcing taxonomies [75], on what types of contributions people are more prone to propose [24,69], on the quality of crowdsourcing contributions relatively to internal research and development (R\&D) outcomes [21], on the best individuals to involve $[70,71,76]$ and on analyzing best practices to manage the campaigns [77-80], without detailing the effects of different kinds of rewards to effectively increase the number of ideas submitted. In particular, we focused on the analysis of the effects on the number of contributions collected brought about by boosting extrinsic and intrinsic motivations, which are the main determinants for crowd participation in volunteer activities like crowdsourcing [29,37], through the use of rewards. In fact, as it happens in other crowd-inclusion phenomena aimed at scientific advancement, including citizen science and open source communities, individuals involved in crowdsourcing may participate in return for a reward and due to self-interest $[33,71,81,82]$. In the first instance, people join a campaign because they are extrinsically motivated, i.e., they contribute in return for some form of personal reward, while in the latter case, participation is realized by leveraging intrinsic motivation, e.g., enjoyment in performing the task or the satisfaction of contributing to a social cause $[10,32,34,37]$. Therefore, companies may leverage both kinds of motivations through the use of rewards, thereby enabling 
companies to collect a greater number of contributions and subsequently increasing the quality of extreme outcomes.

The most widespread form of reward to boost the crowd's extrinsic motivation to participate is money $[35,39,83]$. The positive effect of monetary rewards has been demonstrated in the context of open source communities [39] and of "crowdsourcing of routine activities" [83], while its effect should be clarified in the context of "crowdsourcing of inventive activities". In addition, rewards have been explored in controlled conditions through experiments conducted on intermediary platforms to assess the increase in the intention to participate [43], while here we explore the effect of monetary rewards on the number of ideas collected in real crowdsourcing projects launched by listed companies and managed through their own websites. Moreover, we argue that its effect should be analyzed based on its presence and on the amount. Therefore, we first of all argue that the presence of a monetary reward increases the number of contributions in crowdsourcing projects. The basis for increasing the number of contributions, through the presence of monetary rewards, is the fairness expectation theory: if individuals believe that the benefit distribution system for the project is fair (whereby they receive a personal reward, while the firm benefits by commercializing the crowdsourcing outcome), they are more inclined to participate $[43,44]$.

Consequently, we formulated the following hypothesis:

Hypothesis 1: The presence of monetary rewards positively affects the number of contributions collected in crowdsourcing.

In addition to the presence of monetary rewards, we have independently analyzed the influence of the amount of monetary compensation. We contend that the higher the monetary compensation, the more that people think that only experts can contribute and be compensated. Consequently, the motivation for occasional contributors to participate in these time-consuming activities may be negatively affected by larger monetary compensation. In this scenario, we contend that a higher number of experts will participate in the call, in anticipation of securing a monetary award for participating. Ultimately, the general public, which may represent a valuable resource for out-of-the-box thinking, may be discouraged to participate, thereby diminishing the number of contributions collected, and thus, may negatively impact the quality of the extreme outcomes collected.

In addition to the aforementioned effect, it has also been shown that the intrinsic motivations of crowds may always be present in a campaign involving volunteer participants as happens with crowd-based projects like crowdsourcing, even as a small percentage and they can be negatively impacted by larger monetary rewards resulting in a crowd-out of the participants [84,85]. In fact, larger amounts of monetary rewards may be perceived by volunteers as a mechanism of influence by companies, referred to as "controlling perspective" of rewards [86], which could negatively affect their self-esteem and self-determination, thereby leading to a crowd-out effect [32,87]. Indeed, based on self-determination theory $[36,45-47]$ individuals are intrinsically motivated to participate by enjoying in contributing to the project aim, and large amounts of money could be interpreted by the participants as a controlling mechanism impinging on their independent decision-making [86]. Therefore, the higher the monetary compensation, the more participants feel that money is a controlling factor for companies, and consequently, their intrinsic motivations are diminished. Accordingly, we argue that the greater the monetary compensation, the less the crowd motivation to contribute and consequently, the lower will be the number of contributions collected.

Thus, we formulated a second hypothesis:

Hypothesis 2: The greater the monetary reward, the lower the number of contributions collected in crowdsourcing.

Given that crowdsourcing participants may be motivated by both extrinsic and intrinsic motivations, a non-monetary reward may represent another effective way to increase motivation and 
boost participation in volunteering activities [88]. Previous research has shown that individual benefits, like monetary rewards, do not necessarily conflict with higher-level social objectives, and they can coexist [38,89]. Moreover, drawing from other types of crowd involvement, like citizen science [90-92], where individuals collect and analyze data for research projects, and crowdfunding [93,94], where people financially support new entrepreneurial ventures, rewards, other than pecuniary, have been found to be effective at motivating participants to contribute $[38,95,96]$. According to self-determination theory [36,45-47], the intrinsic motivation to volunteer and contribute to a project can be enhanced with the presence of a social cause. Considering that crowdsourcing can be used for projects that also benefit society, offering a social reward can enhance the intrinsic motivations of the crowd [97,98]. Contributing to a social cause can increase the self-esteem, satisfaction and overall commitment towards responding to the call for ideas. Based on this assumption, we hypothesize that the presence of a social reward increases intrinsic motivation by showing participants that they can benefit society. This will, in turn, motivate participation in crowdsourcing campaigns.

Thus, we formulated a third hypothesis.

Hypothesis 3: The presence of a social benefit positively affects the number of contributions collected in crowdsourcing.

\section{Method}

Using a publicly available database on crowdsourcing campaigns [99], we gathered data related to "crowdsourcing of inventive activities" campaigns conducted during the period 2007-2014. The observations are well spread among the years in question (three for 2007 and 2009, six for 2008, seven for 2013 and 2014, eight for 2011, nine for 2010 and ten for 2012, respectively). The focus of our research was on the "crowdsourcing of inventive activities" initiated by publicly traded companies and managed on their own web-based platform, in order to have equivalent visibility for the general public to calls for ideas from the general public, which allows us to have comparable pools of possible participants. We retrieved information related to the number of contributions collected, the monetary and social benefit rewards from the project descriptions noted in Roth's database [99] and from the corresponding original crowdsourcing website. We ultimately ended up with a sample size of 33 observations. These observations represented the best sample size available and satisfied the limit of 10 observations per variable. This represents a sufficient sample size for conducting an ordinary least square (OLS) linear regression analysis $[38,100]$ to assess the impact of the three independent variables on the dependent variable. In addition, before conducting this analysis, we also conducted a specific power analysis based on the variables we used [101], which demonstrated that the size of this study is sufficient to run the linear regression reported in this study. Moreover, we reported the descriptive statistics in Table 1, to illustrate how they are distributed, and the correlation analysis in Table 2, to highlight the degree to which the variables are correlated.

Table 1. Descriptive statistics.

\begin{tabular}{ccccc}
\hline Variable & Mean & Std. Dev. & Min & Max \\
\hline Number of contributions & $11,249.12$ & $29,092.85$ & 30 & 100,000 \\
Presence of monetary compensation & 0.67 & 0.48 & 0 & 1 \\
Amount of monetary compensation & $53,515.15$ & $176,032.60$ & 0 & $1,000,000$ \\
Presence of a social benefit & 0.18 & 0.39 & 0 & 1 \\
\hline
\end{tabular}


Table 2. Correlations (in brackets is reported the significance level of each correlation).

\begin{tabular}{ccccc}
\hline & $\begin{array}{c}\text { Number of } \\
\text { Contributions }\end{array}$ & $\begin{array}{c}\text { Presence of Monetary } \\
\text { Compensation }\end{array}$ & $\begin{array}{c}\text { Amount of Monetary } \\
\text { Compensation }\end{array}$ & $\begin{array}{c}\text { Presence of a } \\
\text { Social Benefit }\end{array}$ \\
\hline Number of contributions & 1 & & & \\
Presence of monetary & 0.24 & 1 & & \\
compensation & $(0.19)$ & 0.22 & 1 & \\
Amount of monetary & -0.04 & $(0.22)$ & 0.39 & 1 \\
compensation & $(0.81)$ & 0.00 & $(0.03)$ & \multirow{2}{*}{$(1.00)$} \\
Presence of a social benefit & 0.38 & $(0.02)$ & & \\
\hline
\end{tabular}

The dependent variable for our model is represented as the "Number of contributions" collected. Then, by dissecting the project description, we were able to identify: (i) Whether there was monetary compensation, (ii) the amount of compensation, and (iii) the presence or absence of a social benefit for the project. Thus, the three independent variables are: "Presence of monetary compensation", which is a binary variable (presence of monetary compensation $=1$, absence of monetary compensation $=0$ ), "Amount of the monetary compensation", which is a continuous variable value between 0 and $1,000,000$, and "Presence of a social benefit", which is a binary variable (presence of a social benefit $=1$, absence of a social benefit $=0$ ). The correlations, reported in Table 2 , indicate that there are no multicollinearity issues among the variables.

\section{Results}

The results of our OLS regression are reported in Table 3. The significance level at which the analyses are conducted is set to $p<0.10$. In fact, stricter levels of significance have been shown not to be crucial [102], and the use of $p<0.10$ threshold is increasingly being used by many studies in different field as the borderline level of significance for scientific empirical studies [103-107]. The Fisher test provides evidence for the significance of the model tested. Furthermore, the variance inflation factor test demonstrates that multicollinearity was not an issue in our sample. Moreover, the value of the $\mathrm{R}^{2}$ demonstrates that the model is able to explain more than $27 \%$ of the variation of the dependent variable, which is substantial considering the limited sample size available.

Concerning the effect of the independent variable, the impact of "Presence of monetary compensation" is shown to be positive and significant, meaning that the presence of monetary compensation increases the number of contributions. Moreover, the variable "Amount of monetary compensation" has a significantly negative effect, meaning that the higher the value of the compensation, the less likely the organization will attract contributions. Finally, the binary variable "Presence of a social benefit" positively influences the number of contributions collected.

Table 3. Ordinary least square OLS with "Number of contributions" as dependent variable.

\begin{tabular}{cccc}
\hline \multicolumn{4}{c}{ OLS Linear Regression Model } \\
\hline Prob $>$ F & 0.024 \\
\hline R-squared & 0.274 \\
\hline Variable & Coefficient & Std. Error & $p$-value \\
\hline Presence of monetary compensation & $18,365.88$ & 9897.90 & 0.074 \\
Amount of monetary compensation & -0.05 & 0.03 & 0.096 \\
Presence of a social benefit & $37,008.35$ & $12,816.74$ & 0.007 \\
Intercept & -5033.34 & 8189.89 & 0.544 \\
\hline
\end{tabular}

\section{Discussion}

As there is a link between the number of ideas collected and the quality of the extreme outcomes, i.e., the most valuable ideas, finding strategies to increase the number of contributions collected result is crucial. Among the possible methods to achieve this aim, it is possible to use rewards to 
leverage the extrinsic and intrinsic motivation of the crowd. While previous studies analyzed the impact of rewards on other crowd-based activities, e.g., citizen science, open source communities and "crowdsourcing of routine activities" [39-42,83], this study focused on "crowdsourcing of inventive activities", i.e., crowdsourcing projects devoted to provide solutions to companies' complex problems and help them innovate.

In this study, we firstly analyzed the effects brought about by monetary compensation, by analyzing the impact of its presence and of the amount of money being offered. More specifically, the presence of monetary compensation has a positive impact on the number of contributions, thereby supporting Hypothesis 1 . Based on the fairness expectations theory [43,44], people are more inclined to participate if the distribution of benefits, derived from the interaction between the firm and the crowd, is equally balanced among all parties involved. Therefore, it is critical for companies to clearly explain that monetary compensation is offered to the crowd.

Nevertheless, there is also an effect related to the amount of the monetary reward offered, based on self-determination theory [36,45-47] and on the "hidden cost of rewards" concept [108]. Large monetary rewards can be detrimental to attracting participants, resulting in a crowd-out effect. Indeed, the results of this study demonstrated a negative impact induced by the value of the monetary compensation on the number of contributions achieved, thereby supporting Hypothesis 2. This negative effect is due to the fact that people may be discouraged to participate because they think that only experts can make insightful contributions and be compensated. This result is also in line with previous research findings about the negative effects that higher monetary compensation has on voluntary activities participation $[84,85]$. Monetary compensation may, in fact, reduce contributors' intrinsic motivation to voluntarily participate because increased compensation can be perceived as the company's controlling mechanism. Thus, higher compensation may ultimately result in a crowd-out effect, i.e., a reduction in participant motivation and in in the number of contributions. By disentangling the positive effects of monetary compensation, and the negative impact brought about by the amount of compensation being offered, we offer a notable contribution to the discussion about the impact of monetary rewards on crowdsourcing [89] and have produced a foundation for a more comprehensive theoretical understanding on its effects. Furthermore, we have suggested how monetary rewards can be optimized to attract more contributors, i.e., rewards should be present but not with excessive amounts.

Finally, in this study, we also identified how the presence of a non-monetary reward, i.e., a social benefit like contributing to reducing $\mathrm{CO}_{2}$ emissions or clean water campaigns linked to crowdsourcing innovation outcomes, can increase the number of participants in a crowdsourcing campaign. Our research demonstrates that the presence of a social reward that support social causes, like tackling the emission of pollutants into the atmosphere or decreasing man-made waste in the oceans, can further motivate participants, thereby supporting Hypothesis 3.

In the following subsections, we detail the contributions, the limitations and possible further developments of this research.

\subsection{Contributions}

Crowdsourcing is an increasingly adopted tool by companies to innovate, and consequently, there is a managerial and academic growing interest towards understanding this phenomenon $[12,15,23,24$, $55,56,72]$. While previous studies primarily analyzed (i) crowdsourcing taxonomies [75], (ii) which types of contributions people are more prone to propose [24,69], (iii) the quality of crowdsourcing contributions relative to internal R\&D outcomes [77], (iv) which individuals are more suited to a campaign [70,71,76] and (v) best practices to manage crowdsourcing campaigns [77-80], we focused on analyzing the effects of different kinds of rewards to increase the number of ideas submitted. It is, indeed, crucial to maximize the quality of the ideas collected to develop better products and services for the marketplace, and this is strictly linked to the amount of contributions collected [28]. Thus, our study provides evidence on the impact of monetary and social rewards. While one kind of reward at a time has been considered by previous studies [43,49], we analyzed the effect of the simultaneous 
presence of monetary and social reward, by dissecting the pecuniary reward into its presence and amount. We contribute to the literature on crowdsourcing by demonstrating how to increase the number of contributions by effectively designing a campaign with appropriate monetary and social rewards. By doing so, we respond to the call for studies regarding a better design of crowdsourcing as noted by Zheng and colleagues [49], thereby highlighting how companies should include a monetary reward, although not in an excessive amount, while being paired with a social cause to maximize the number of contributions from the crowd.

Moreover, monetary incentives were shown to be beneficial in "crowdsourcing of routine activities" [83], while Lepper and Green [108] introduced the concept of the "hidden cost of rewards" as monetary rewards can also be detrimental to motivating the crowd to participate. Consequently, the effect of monetary rewards in the "crowdsourcing of inventive activities" requires further analysis. Therefore, with this study, by dissecting the effects of monetary rewards into the positive effect due to its presence and the negative effect due to its amount, we provide theoretical support for these effects and provide a better understanding of the impact of monetary rewards on crowdsourcing.

In addition, we have provided support for our hypotheses, based on the simultaneous effects brought about by monetary rewards under fairness expectation and self-determination theories [36,45-47]. While a comprehensive theory of OI is still lacking [109,110] and different theoretical lenses have been applied so far to crowdsourcing [49,69,70], we stress the importance of considering fairness expectation and self-determination theory to properly understand how to increase the number of contributions collected with a crowdsourcing call for ideas.

Overall, the outcomes of this study theoretically explain and empirically demonstrate that both extrinsic and intrinsic motivations should be leveraged to attract greater participation and increase the number of contributions, respectively, with monetary and social rewards. These results extend to the context of crowdsourcing the assertion that individual benefits, such as monetary compensation, can be attained together with higher-level objectives, such as social benefits $[39,89]$. Furthermore, this paper also offers an empirical advancement with respect to previous studies. In fact, while previous studies analyzed crowdsourcing projects carried out on integrators web-based platforms (i.e., managed by third parties), and conducted research on campaigns conducted mainly in one country [43,48,111-114], we stressed the importance of relying on "crowdsourcing of inventive activities", which deals with providing solutions to companies' complex problems and helping them to innovate. Moreover, we focused on crowdsourcing calls launched by listed companies worldwide and managed on their own website in order to have comparable visibility of the call for ideas for the crowd of possible participants.

\subsection{Limitations and Future Research}

This study is not exempt from limitations that also pave the way for several future developments. First, the sample has a limited size due to the focus on the "crowdsourcing of inventive activities" calls launched by listed firms and managed on their own platform. Thus, future studies should confirm the results obtained in this research by using more observations and over a longer period of time. Additionally, we only focused on crowdsourcing campaigns launched by listed companies when comparing different crowdsourcing campaigns but in order to have comparable visibility with respect to the call for ideas for the general public unlisted companies should also be examined. Another interesting research perspective would be to consider crowdsourcing campaigns for private firms, which should be characterized by different financial and human resources $[115,116]$. Moreover, future studies can extend the analysis to the other types of crowdsourcing, i.e., "crowdsourcing of content" and "crowdsourcing of routine activities" to further generalize our findings that are now related specifically to "crowdsourcing of inventive activities".

\section{Conclusions}

Our research findings, although drawn from a limited sample size, which should be broadened in future studies, contribute to a better scientific understanding of the crowdsourcing 
phenomenon $[15,20,21,55,56]$ by providing empirical evidence about how monetary and social rewards can increase participant motivation and influence the number of contributions. Indeed, the number of contributions collected is a proxy for the quality of the outcomes collected through crowdsourcing which aid companies to deliver innovative products and services [28]. More specifically, we proved the importance of the fairness expectation and self-determination theories $[32,36,37,43-47]$ to assess how monetary compensation affects the number of ideas collected in crowdsourcing. Furthermore, while crowdsourcing is mainly associated with pecuniary rewards, we found that offering a social benefit, as an additional non-monetary reward, could increase the number of contributions.

In addition, demonstrating how to collect a greater number of ideas through crowdsourcing also represents a relevant outcome for managers, as companies will more likely gain extreme outcomes, i.e., valuable input from a crowdsourcing campaign towards innovation. Additionally, as policymakers seek out new opportunities to face grand challenges, i.e., social and environmental global objectives $[117,118]$, the outcomes of this study suggest that it is effective to add a social cause to crowdsourcing campaigns. By so doing it would be possible to collect more contributions and improve innovation, which may benefit the firm itself and also the community.

To conclude, our study stresses the importance of both personal and social rewards for individuals participating in crowdsourcing, thereby providing further evidence about the feasibility of the Open Sustainable Innovation framework, i.e., efforts in generating innovative and also sustainable outcomes, in terms of positively impacting social welfare, the environment and the economic wealth of the companies involved [38,119-121], through OI [11,122,123].

Author Contributions: Conceptualization, F.C., F.R. and D.H.; methodology, F.C., F.R. and D.H.; data curation, F.C. and F.R.; formal analysis, F.C. and F.R.; writing-original draft preparation, F.C.; writing-review and editing, F.C., F.R. and D.H.; supervision, D.H.; funding acquisition, F.C. and F.R.

Funding: Francesco Cappa and Federica Rosso have been supported by Ermenegildo Zegna with the EZ Founder's Scholarship program 2017-2018 and 2018-2019.

Acknowledgments: Francesco Cappa would like to acknowledge Dr. Sergio Marchionne who has been an inspiration throughout the last 10 years pushing towards innovative thinking and ambitious goals, always with a socially responsible attitude.

Conflicts of Interest: The authors declare no conflict of interest. The funders had no role in the design of the study; in the collection, analyses, or interpretation of data; in the writing of the manuscript, or in the decision to publish the results.

\section{References}

1. Enkel, E.; Gassmann, O.; Chesbrough, H. Open R\&D and open innovation: Exploring the phenomenon. Rd Manag. 2009, 39, 311-316.

2. West, J.; Salter, A.; Vanhaverbeke, W.; Chesbrough, H. Open innovation: The next decade. Res. Policy 2014, 43, 805-811. [CrossRef]

3. Chesbrough, H. The New Imperative for Creating and Profiting from Technology; Harvard Business School: Boston, MA, USA, 2003; Volume 2006.

4. Michelino, F.; Lamberti, E.; Cammarano, A.; Caputo, M. Open Innovation in the Pharmaceutical Industry: An Empirical Analysis on Context Features, Internal R\&D, and Financial Performances. IEEE Trans. Eng. Manag. 2015, 62, 1-15.

5. Cammarano, A.; Michelino, F.; Lamberti, E.; Caputo, M. Accumulated stock of knowledge and current search practices: The impact on patent quality. Technol. Forecast. Soc. Chang. 2017, 120, 204-222. [CrossRef]

6. Huizingh, E.K.R.E. Open innovation: State of the art and future perspectives. Technovation 2011, 31, 2-9. [CrossRef]

7. Lamberti, E.; Michelino, F.; Cammarano, A.; Caputo, M. Open innovation scorecard: A managerial tool. Bus. Process Manag. J. 2017, 23, 1216-1244. [CrossRef]

8. Cammarano, A.; Caputo, M.; Lamberti, E.; Michelino, F. Open innovation and intellectual property: A knowledge-based approach. Manag. Decis. 2017, 55, 1182-1208. [CrossRef] 
9. Michelino, F.; Cammarano, A.; Lamberti, E.; Caputo, M. Measurement of open innovation through intellectual capital flows: Framework and application. Int. J. Intell. Enterp. 2014, 2, 213-215. [CrossRef]

10. Franzoni, C.; Sauermann, H. Crowd science: The organization of scientific research in open collaborative projects. Res. Policy 2014, 43, 1-20. [CrossRef]

11. Cappa, F.; Del Sette, F.; Hayes, D.; Rosso, F. How to deliver open sustainable innovation: An integrated approach for a sustainable marketable product. Sustainability 2016, 8, 1341. [CrossRef]

12. Bayus, B.L. Crowdsourcing New Product Ideas over Time: An Analysis of the Dell IdeaStorm Community. Manag. Sci. 2013, 59, 226-244. [CrossRef]

13. Howe, J. The Rise of Crowdsourcing. Wired Mag. 2006, 14, 1-5.

14. Brabham, D.C. The Myth of Amateur Crowds. Inf. Commun. Soc. 2012, 15, 394-410. [CrossRef]

15. Afuah, A.; Tucci, C.L. Crowdsourcing as a solution to distant search. Acad. Manag. Rev. 2012, 3, 355-375. [CrossRef]

16. Michelino, F.; Cammarano, A.; Lamberti, E.; Caputo, M. Open innovation for start-ups: A patent-based analysis of bio-pharmaceutical firms at the knowledge domain level. Eur. J. Innov. Manag. 2017, 20, 112-134. [CrossRef]

17. Surowiecki, J. The Wisdom of Crowds; Anchor Books: New York, NY, USA, 2006; Volume 75.

18. Maiolini, R.; Naggi, R. Crowdsourcing and SMEs: Opportunities and Challenges. In Information Technology and Innovation Trends in Organizations; Physica-Verlag HD: Heidelberg, Germany, 2011; pp. 399-406.

19. Magnusson, P.R. Exploring the Contributions of Involving Ordinary Users in Ideation of Technology-Based Services. J. Prod. Innov. Manag. 2009, 26, 578-593. [CrossRef]

20. Schemmann, B.; Herrmann, A.M.; Chappin, M.M.H.; Heimeriks, G.J. Crowdsourcing ideas: Involving ordinary users in the ideation phase of new product development. Res. Policy 2016, 45, 1145-1154. [CrossRef]

21. Poetz, M.K.; Schreier, M. The value of crowdsourcing: Can users really compete with professionals in generating new product ideas? J. Prod. Innov. Manag. 2012, 29, 245-256. [CrossRef]

22. Walsh, J.P.; Lee, Y.N.; Nagaoka, S. Openness and innovation in the US: Collaboration form, idea generation and implementation. Res. Policy 2016, 45, 1660-1671. [CrossRef]

23. Angus, L. Small firms, Start-ups Drive Crowdsourcing Growth. Available online: https://www.wsj.com/ articles/SB10001424052970204653604577251293100111420 (accessed on 5 June 2017).

24. Ghezzi, A.; Gabelloni, D.; Martini, A.; Natalicchio, A. Crowdsourcing: A Review and Suggestions for Future Research. Int. J. Manag. Rev. 2017, 20, 343-363. [CrossRef]

25. Afuah, A.; Tucci, C.L. Value capture and crowdsourcing. Acad. Manag. Rev. 2013, 38, 457-460. [CrossRef]

26. Björk, J.; Magnusson, M. Where do good innovation ideas come from? Exploring the influence of network connectivity on innovation idea quality. J. Prod. Innov. Manag. 2009, 26, 662-670. [CrossRef]

27. Van den Ende, J.; Frederiksen, L.; Prencipe, A. The Front End of Innovation: Organizing Search for Ideas. J. Prod. Innov. Manag. 2015, 32, 482-487. [CrossRef]

28. Boudreau, K.J.; Lacetera, N.; Lakhani, K.R. Incentives and Problem Uncertainty in Innovation Contests: An Empirical Analysis. Manag. Sci. 2011, 57, 843-863. [CrossRef]

29. Nov, O.; Arazy, O.; Anderson, D. Scientists@ Home: What drives the quantity and quality of online citizen science participation? PLoS ONE 2014, 9, e90375. [CrossRef] [PubMed]

30. Ebner, W.; Leimeister, J.M.; Krcmar, H. Community engineering for innovations: The ideas competition as a method to nurture a virtual community for innovations. Rd Manag. 2009, 39, 342-356. [CrossRef]

31. Wilson, M.; Robson, K.; Botha, E. Crowdsourcing in a time of empowered stakeholders: Lessons from crowdsourcing campaigns. Bus. Horiz. 2017, 60, 247-253. [CrossRef]

32. Deci, E.L.; Ryan, R.M. The "What" and "Why" of goal pursuits: Human needs and the self-determination of behavior. Psychol. Inq. 2000, 11, 227-268. [CrossRef]

33. Wasko, M.M.; Faraj, S. Why Should I Share? Examining Social Capital and Knowledge Contribution in Electronic Networks of Practice. Mis Q. 2005, 29, 35-57. [CrossRef]

34. Antikainen, M.; Mäkipää, M.; Ahonen, M. Motivating and supporting collaboration in open innovation. Eur. J. Innov. Manag. 2010, 13, 100-119. [CrossRef]

35. Brabham, D.C. Crowdsourcing as a Model for Problem Solving: An Introduction and Cases. Converg. Int. J. Res. Into New Media Technol. 2008, 14, 75-90. [CrossRef]

36. Deci, E.L.; Ryan, R.M. Self-determination theory in health care and its relations to motivational interviewing: A few comments. Int. J. Behav. Nutr. Phys. Act. 2012, 9, 1-6. [CrossRef] 
37. Cappa, F.; Laut, J.; Porfiri, M.; Giustiniano, L. Bring them aboard: Rewarding participation in technology-mediated citizen science projects. Comput. Hum. Behav. 2018, 89, 246-257. [CrossRef]

38. Cappa, F.; Laut, J.; Nov, O.; Giustiniano, L.; Porfiri, M. Activating social strategies: Face-to-face interaction in technology-mediated citizen science. J. Environ. Manag. 2016, 182, 374-384. [CrossRef] [PubMed]

39. Krishnamurthy, S.; Ou, S.; Tripathi, A.K. Acceptance of monetary rewards in open source software development. Res. Policy 2014, 43, 632-644. [CrossRef]

40. Newman, G.; Zimmerman, D.; Crall, A.; Laituri, M.; Graham, J.; Stapel, L. User-friendly web mapping: Lessons from a citizen science website. Int. J. Geogr. Inf. Sci. 2010, 24, 1851-1869. [CrossRef]

41. Sullivan, B.L.; Aycrigg, J.L.; Barry, J.H.; Bonney, R.E.; Bruns, N.; Cooper, C.B.; Damoulas, T.; Dhondt, A.A.; Dietterich, T.; Farnsworth, A.; et al. The eBird enterprise: An integrated approach to development and application of citizen science. Biol. Conserv. 2014, 169, 31-40. [CrossRef]

42. Newman, G.; Wiggins, A.; Crall, A.; Graham, E.; Newman, S.; Crowston, K. The future of Citizen science: Emerging technologies and shifting paradigms. Front. Ecol. Environ. 2012, 10, 298-304. [CrossRef]

43. Franke, N.; Keinz, P.; Klausberger, K. “Does This Sound Like a Fair Deal?": Antecedents and Consequences of Fairness Expectations in the Individual's Decision to Participate in Firm Innovation. Organ. Sci. 2013, 24, 1495-1516. [CrossRef]

44. Faullant, R.; Fueller, J.; Hutter, K. Fair play: Perceived fairness in crowdsourcing competitions and the customer relationship-related consequences. Manag. Decis. 2017, 55, 1924-1941. [CrossRef]

45. Gagné, M.; Deci, E.L. Self-determination theory and work motivation. J. Organ. Behav. 2005, 26, 331-362. [CrossRef]

46. Ryan, R.M.; Deci, E.L. Self-determination theory and the facilitation of intrinsic motivation, social development and well-being. Am. Psychol. 2000, 55, 68-78. [CrossRef]

47. Ryan, R.M.; Deci, E.L. When rewards compete with nature: The undermining of intrinsic motivation and self-regulation. In Intrinsic and Extrinsic Motivation: The Search for Optimal Motivation and Performance; Academic Press: Cambridge, UK, 2000; pp. 13-54.

48. Kohler, T.; Nickel, M. Crowdsourcing business models that last. J. Bus. Strategy 2017, 38, 25-32. [CrossRef]

49. Zheng, H.; Li, D.; Hou, W. Task Design, Motivation, and Participation in Crowdsourcing Contests. Int. J. Electron. Commer. 2011, 15, 57-88. [CrossRef]

50. Pollok, P.; Lüttgens, D.; Piller, F.T. Attracting solutions in crowdsourcing contests: The role of knowledge distance, identity disclosure, and seeker status. Res. Policy 2019, 48, 98-114. [CrossRef]

51. Silvertown, J.; Harvey, M.; Greenwood, R.; Dodd, M.; Rosewell, J.; Rebelo, T.; Ansine, J.; McConway, K. Crowdsourcing the identification of organisms: A case-study of iSpot. ZooKeys 2015, 480, 125-146. [CrossRef]

52. See, L.; Fritz, S.; Perger, C.; Schill, C.; McCallum, I.; Schepaschenko, D.; Duerauer, M.; Sturn, T.; Karner, M.; Kraxner, F.; et al. Harnessing the power of volunteers, the internet and Google Earth to collect and validate global spatial information using Geo-Wiki. Technol. Forecast. Soc. Chang. 2015, 98, 324-335. [CrossRef]

53. Garcia Martinez, M. Inspiring crowdsourcing communities to create novel solutions: Competition design and the mediating role of trust. Technol. Forecast. Soc. Chang. 2017, 117, 296-304. [CrossRef]

54. Piazza, M.; Mazzola, E.; Acur, N.; Perrone, G. Governance Considerations for Seeker-Solver Relationships: A Knowledge-Based Perspective in Crowdsourcing for Innovation Contests. Br. J. Manag. 2019, accepted. [CrossRef]

55. Ford, R.C.; Richard, B.; Ciuchta, M.P. Crowdsourcing: A new way of employing non-employees? Bus. Horiz. 2015, 58, 377-388. [CrossRef]

56. Garcia Martinez, M. Solver engagement in knowledge sharing in crowdsourcing communities: Exploring the link to creativity. Res. Policy 2015, 44, 1419-1430. [CrossRef]

57. Majchrzak, A.; Malhotra, A. Towards an information systems perspective and research agenda on crowdsourcing for innovation. J. Strateg. Inf. Syst. 2013, 22, 257-268. [CrossRef]

58. Mina, A.; Bascavusoglu-Moreau, E.; Hughes, A. Open service innovation and the firm's search for external knowledge. Res. Policy 2014, 43, 853-866. [CrossRef]

59. Benner, M.J.; Tushman, M. Reflections on the 2013 Decade Award: “Exploitation, Exploration, and Process Management: The Productivity Dilemma Revisited" ten years later. Acad. Manag. Rev. 2015, 40, 479-514. [CrossRef]

60. Laut, J.; Cappa, F.; Nov, O.; Porfiri, M. Increasing Citizen Science Contribution Using a Virtual Peer. J. Assoc. Inf. Sci. Technol. 2017, 68, 583-593. [CrossRef] 
61. Plesner, U.; Gulbrandsen, I.T. Strategy and new media: A research agenda. Strateg. Organ. 2015, 13, $153-162$. [CrossRef]

62. Brossard, D.; Lewenstein, B.; Bonney, R. Scientific knowledge and attitude change: The impact of a citizen science project. Int. J. Sci. Educ. 2005, 27, 1099-1121. [CrossRef]

63. Laut, J.; Cappa, F.; Nov, O.; Porfiri, M. Increasing patient engagement in rehabilitation exercises using computer-based citizen science. PLoS ONE 2015, 10, e0117013. [CrossRef]

64. Erkut, B. The Emergence of the ERP Software Market between Product Innovation and Market Shaping. J. Open Innov. Technol. Mark. Complex. 2018, 4, 23. [CrossRef]

65. Von Hippel, E. Democratizing innovation. J. Für Betr. 2005, 55, 63-78. [CrossRef]

66. Jeppesen, L.B.; Frederiksen, L. Why Do Users Contribute to Firm-Hosted User Communities? The Case of Computer-Controlled Music Instruments. Organ. Sci. 2006, 17, 45-63. [CrossRef]

67. Herstatt, C.; Von Hippel, E.A. From experience: Developing new product concepts via the lead user method: A case study in a "low tech" field. J. Prod. Innov. Manag. 1992, 9, 213-221. [CrossRef]

68. Franke, N.; Von Hippel, E.; Schreier, M. Finding commercially attractive user innovations: A test of lead-user theory. J. Prod. Innov. Manag. 2006, 23, 301-315. [CrossRef]

69. Penin, J.; Burger-Helmchen, T. Crowdsourcing of inventive activities: Definition and limits. Int. J. Innov. Sustain. Dev. 2011, 5, 246-263. [CrossRef]

70. Füller, J.; Matzler, K.; Hutter, K.; Hautz, J. Consumers' Creative Talent: Which Characteristics Qualify Consumers for Open Innovation Projects? An Exploration of Asymmetrical Effects. Creat. Innov. Manag. 2012, 21, 247-262. [CrossRef]

71. Füller, J.; Hutter, K.; Faullant, R. Why co-creation experience matters? Creative experience and its impact on the quantitty and quality of creative contributions. Rd Manag. 2011, 41, 259-273.

72. Blohm, I.; Leimeister, J.M.; Krcmar, H. Crowdsourcing: How to Benefit from (Too) Many Great Ideas. Mis Q. Exec. 2013, 412, 199-211.

73. Caputo, M.; Lamberti, E.; Cammarano, A.; Michelino, F. Exploring the impact of open innovation on firm performances. Manag. Decis. 2016, 54, 1788-1812. [CrossRef]

74. Lamberti, E.; Caputo, M.; Michelino, F.; Cammarano, A. How to measure collaboration in an open innovation context. Int. J. Bus. Innov. Res. 2017, 14, 301. [CrossRef]

75. Estellés-Arolas, E.; González-Ladrón-de-Guevara, F. Towards an integrated crowdsourcing definition. J. Inf. Sci. 2012, 38, 189-200. [CrossRef]

76. Lüthje, C.; Herstatt, C.; von Hippel, E. User-innovators and "local” information: The case of mountain biking. Res. Policy 2005, 34, 951-965. [CrossRef]

77. Feller, J.; Finnegan, P.; Hayes, J.; O’Reilly, P. “Orchestrating” sustainable crowdsourcing: A characterisation of solver brokerages. J. Strateg. Inf. Syst. 2012, 21, 216-232. [CrossRef]

78. Kulkarni, A.; Gutheim, P.; Narula, P.; Rolnitzky, D.; Parikh, T.; Hartmann, B. Mobileworks: Designing for quality in a managed crowdsourcing architecture. IEEE Internet Comput. 2012, 16, 28-35. [CrossRef]

79. Vuurens, J.B.P.; De Vries, A.P. Obtaining high-quality relevance judgments using crowdsourcing. IEEE Internet Comput. 2012, 16, 20-27. [CrossRef]

80. Hewig, M. Merits of collaboration with potential and current users in creative problem-solving. Int. J. Innov. Manag. 2013, 17, 1-28.

81. Lakhani, K.R.; Wolf, R.G. Why Hackers Do What They Do: Understanding Motivation and Effort in Free/Open Source Software Projects. In Perspectives on Free and Open Source Software; MIT Press: Cambridge, UK, 2005; Volume 3.

82. Raddick, M.J.; Bracey, G.; Gay, P.L.; Lintott, C.J.; Cardamone, C.; Murray, P.; Schawinski, K.; Szalay, A.S.; Vandenberg, J. Galaxy zoo: Motivations of citizen scientists. Astron. Educ. Rev. 2013, 12, 12.

83. Paolacci, G.; Chandler, J.; Ipeirotis, P. Running experiments on amazon mechanical turk. Judgm. Decis. Mak. 2010, 5, 411-419.

84. Titmuss, R. The gift of blood. Society 1998, 35, 88-97. [CrossRef]

85. Fiorillo, D. Do Monetary Rewards Crowd Out the Intrinsic Motivation of Volunteers? Some Empirical Evidence for Italian Volunteers. Ann. Public Coop. Econ. 2011, 82, 139-165. [CrossRef]

86. Grandey, A.A.; Chi, N.W.; Diamond, J.A. Show me The Money! Do Financial Rewards for Performance Enhance or Undermine The Satisfaction from Emotional Labor? Pers. Psychol. 2013, 66, 569-612. [CrossRef] 
87. Miller, K.A.; Deci, E.L.; Ryan, R.M. Intrinsic Motivation and Self-Determination in Human Behavior. Contemp. Sociol. 1988, 17, 253. [CrossRef]

88. Costa-Font, J.; Jofre-Bonet, M.; Yen, S.T. Not All Incentives Wash Out the Warm Glow: The Case of Blood Donation Revisited. Kyklos 2013, 66, 529-551. [CrossRef]

89. Bonaccorsi, A.; Rossi, C. Why Open Source software can succeed. Res. Policy 2003, 32, 1243-1258. [CrossRef]

90. Follett, R.; Strezov, V. An analysis of citizen science based research: Usage and publication patterns. PLoS ONE 2015, 10, e0143687. [CrossRef] [PubMed]

91. Wildschut, D. The need for citizen science in the transition to a sustainable peer-to-peer-society. Futures 2017, 91, 46-52. [CrossRef]

92. Bonney, R.; Cooper, C.B.; Dickinson, J.; Kelling, S.; Phillips, T.; Rosenberg, K.V.; Shirk, J. Citizen science: A developing tool for expanding science knowledge and scientific literacy. BioScience 2009, 59, 977-984. [CrossRef]

93. Centobelli, P.; Cerchione, R.; Esposito, E.; Raffa, M. The revolution of crowdfunding in social knowledge economy: Literature review and identification of business models. Adv. Sci. Lett. 2016, 22, 1666-1669. [CrossRef]

94. Mollick, E. The dynamics of crowdfunding: An exploratory study. J. Bus. Ventur. 2014, 29, 1-16. [CrossRef]

95. Lehner, O.M. Crowdfunding social ventures: A model and research agenda. Ventur. Cap. 2013, 15, $289-311$. [CrossRef]

96. Calic, G.; Mosakowski, E. Kicking Off Social Entrepreneurship: How A Sustainability Orientation Influences Crowdfunding Success. J. Manag. Stud. 2016, 53, 738-767. [CrossRef]

97. Eisenberger, R.; Pierce, W.D.; Cameron, J. Effects of reward on intrinsic motivation-Negative, neutral and positive: Comment on Deci, Koestner, and Ryan (1999). Psychol. Bull. 1999, 125, 677-691; discussion 692-700. [CrossRef] [PubMed]

98. Cameron, J.; Banko, K.M.; Pierce, W.D. Pervasive negative effects of rewards on intrinsic motivation: The myth continues. Behav. Anal. 2001, 24, 1-44. [CrossRef] [PubMed]

99. Roth, Y. Crowdsourcing Timeline. Available online: http://www.tiki-toki.com/timeline/entry/52997/ Crowdsourcing-by-Worlds-Best-Global-Brands/\#vars!date=2015-01-10_17:48:12! (accessed on 4 December 2015).

100. Austin, P.C.; Steyerberg, E.W. The number of subjects per variable required in linear regression analyses. J. Clin. Epidemiol. 2015, 68, 627-636. [CrossRef]

101. Lenth, R.V. Java Applets for Power and Sample Size. Available online: http://www.stat.uiowa.edu/ \{\{rlenth/ Power (accessed on 26 March 2019).

102. Mcshane, B.B.; Gal, D.; Gelman, A.; Robert, C.; Tackett, J.L. Abandon Statistical Significance. Am. Stat. 2019, 73, 235-245. [CrossRef]

103. Van der Zwan, P.; Thurik, R.; Verheul, I.; Hessels, J. Factors influencing the entrepreneurial engagement of opportunity and necessity entrepreneurs. Eurasian Bus. Rev. 2016, 6, 273-295. [CrossRef]

104. Karl, T.R.; Arguez, A.; Huang, B.; Lawrimore, J.H.; McMahon, J.R.; Menne, M.J.; Peterson, T.C.; Vose, R.S.; Zhang, H.M. Possible artifacts of data biases in the recent global surface warming hiatus. Science 2015, 348, 1469-1472. [CrossRef]

105. Wilks, D.S. "The stippling shows statistically significant grid points": How research results are routinely overstated and overinterpreted, and what to do about it. Bull. Am. Meteorol. Soc. 2016, 97, 2263-2273. [CrossRef]

106. Bouri, E.; Molnár, P.; Azzi, G.; Roubaud, D.; Hagfors, L.I. On the hedge and safe haven properties of Bitcoin: Is it really more than a diversifier? Financ. Res. Lett. 2017, 20, 192-198. [CrossRef]

107. Johnson, P.F.; Leenders, M.R.; McCue, C. A comparison of purchasing's organizational roles and responsibilities in the public and private sector. J. Public Procure. 2018, 3, 57-74. [CrossRef]

108. Lepper, M.; Greene, D. The Hidden Cost of Reward: New Perspectives on Psychology of Human Behavior; Associates, E., Ed.; Hillsdale: New York, NY, USA, 1978.

109. Randhawa, K.; Wilden, R.; Hohberger, J. A Bibliometric Review of Open Innovation: Setting a Research Agenda. J. Prod. Innov. Manag. 2016, 33, 750-772. [CrossRef]

110. Busse, C.; Kach, A.P.; Wagner, S.M. Boundary Conditions: What They Are, How to Explore Them, Why We Need Them, and When to Consider Them. Organ. Res. Methods 2017, 20, 574-609. [CrossRef]

111. Brabham, D.C. Moving the crowd at Threadless. Inf. Commun. Soc. 2010, 13, 1122-1145. [CrossRef] 
112. Brabham, D.C. Moving the crowd at iStockphoto: The composition of the crowd and motivations for participation in a crowdsourcing application. First Monday 2008, 13, 1-19. [CrossRef]

113. Straub, T.; Gimpel, H.; Teschner, F.; Weinhardt, C. How (not) to Incent Crowd Workers. Bus. Inf. Syst. Eng. 2015, 57, 167-179. [CrossRef]

114. Vuculescu, O.; Bergenholtz, C. How to Solve Problems with Crowds: A Computer-Based Simulation Model. Creat. Innov. Manag. 2014, 23, 121. [CrossRef]

115. Acharya, V.; Zhaoxia, X. Financial dependence and innovation: The case of public versus private firms. J. Financ. Econ. 2017, 124, 223-243. [CrossRef]

116. Durand, R.; Vargas, V. Ownership, organization, and private firms' efficient use of resources. Strateg. Manag. J. 2003, 24, 667-675. [CrossRef]

117. Foray, D.; Mowery, D.; Nelson, R. Public R\&D and social challenges: What lessons from mission R\&D programs? Res. Policy 2012, 41, 1697-1792.

118. Kuhlmann, S. The Challenge of Addressing Grand Challenge. 2014. Available online: https://ris.utwente.nl/ws/ portalfiles/portal/5140568/The_challenge_of_addressing_Grand_Challenges.pdf (accessed on 17 May 2019).

119. Hayes, D.R.; Cappa, F. Open-source intelligence for risk assessment. Bus. Horiz. 2018, 61, 689-697. [CrossRef]

120. Maxwell, D.; Van der Vorst, R. Developing sustainable products and services. J. Clean. Prod. 2003, 11, 883-895. [CrossRef]

121. Morelli, J. Environmental Sustainability: A Definition for Environmental Professionals. J. Environ. Sustain. 2011, 1, 1-27. [CrossRef]

122. Arcese, G.; Flammini, S.; Lucchetti, M.C.; Martucci, O. Open Sustainability Innovation in the Food Sector. Sustainability 2014, 7, 8067-8090. [CrossRef]

123. Boons, F.; Montalvo, C.; Quist, J.; Wagner, M. Sustainable innovation, business models and economic performance: An overview. J. Clean. Prod. 2013, 45, 1-8. [CrossRef]

(C) 2019 by the authors. Licensee MDPI, Basel, Switzerland. This article is an open access article distributed under the terms and conditions of the Creative Commons Attribution (CC BY) license (http://creativecommons.org/licenses/by/4.0/). 